\title{
Polyamine, Magnesium and Ribonucleic Acid Levels in Steady-state Cultures of the Mould Aspergillus nidulans
}

\author{
By M. E. BUSHELL AND A. T. BULL \\ Biological Laboratory, University of Kent, Canterbury CT2 $7 \mathrm{NJ}$
}

(Received 2 October 1973 ; revised 6 November 1973)

Results from experiments in vitro strongly suggest that major roles can be ascribed to polyamines in controlling the stability, activity and synthesis of ribonucleic acids. Furthermore, functional substitution of polyamines for inorganic cations, particularly magnesium ions, in cell-free protein synthesis is well substantiated (see Cohen, I97I). Recently we have been analysing the effects of culture conditions on the chemical composition of Aspergillus nidulans and have found fluctuations in polyamine and magnesium concentrations in response to a changing environment, while biomass and RNA remained constant. This paper describes the influence of steady-state growth rate on hyphal concentrations of spermidine, spermine and $\mathrm{Mg}^{2+}$ ions.

\section{METHODS}

A hyaline mutant, I3 mel, of Aspergillus nidulans (Bull \& Faulkner, I965) was grown in a chemically defined liquid medium (Carter \& Bull, I969), the $\mathrm{Mg}^{2+}$ concentration of which was I mM. Continuous-flow cultures were made in a 3.21 fermenter unit (L.H. Engineering Ltd), the specifications and operation of which have been detailed by Rowley \& Bull (I973). The fermenter was used in the chemostat mode, the carbon and energy source, glucose, being growth-limiting. The maximum specific growth rate of the mould in the defined medium was $0.20 \mathrm{~h}^{-1}$ and analyses were made at the following steady-state dilution rates: $0.02,0.05,0.07,0.10,0.125$ and $0.175 \mathrm{~h}^{-1}$. At one dilution rate $\left(0.02 \mathrm{~h}^{-1}\right)$ the culture was heterogeneous and comprised vegetative hyphae, conidiophores and free conidia.

Mycelia, thoroughly washed with $0 \cdot$ I I M-phosphate buffered saline, $\mathrm{pH} 6 \cdot 8$, were freezedried and macerated at $0{ }^{\circ} \mathrm{C}$ in $0.2 \mathrm{~N}$-perchloric acid $\left(5 \mathrm{mg}\right.$ mycelium $\left.\mathrm{ml}^{-1}\right)$ by a motordriven Teflon-glass homogenizer (six passes at $750 \mathrm{rev} . / \mathrm{min}$ for Io s). Analysis of the saline washings revealed that neither polyamines nor magnesium ions had been leached from the mycelia. Polyamines in the perchloric acid extract were assayed by the method of Dion \& Herbst (1970). The fluorescent dansyl derivatives were separated on silica-gel thin-layer chromatography plates (Eastman Kodak Co.), eluted by cutting out the spots and extracting the silica gel three times with an ethyl acetate-cyclohexane mixture $(2: 3, v / v)$ and their fluorescence measured in a Perkin Elmer MPF-3 fluorescence spectrometer (wavelength of activating light $365 \mathrm{~nm}$, slit 8; fluorescence measured at $520 \mathrm{~nm}$, slit 8). Magnesium was measured by the Titan-Yellow method (Herbert, Phipps \& Strange, 197I) and three-times extracted macerated mycelium $\left(0 \cdot 2 \mathrm{~N}-\mathrm{HClO}_{4}\right.$ at $\left.70^{\circ} \mathrm{C}\right)$ was assayed for RNA by the Schneider orcinol procedure (Herbert, Phipps \& Strange, 1971). Spermidine, spermine (Sigma) and yeast RNA (BDH Ltd) were used as reference compounds. 


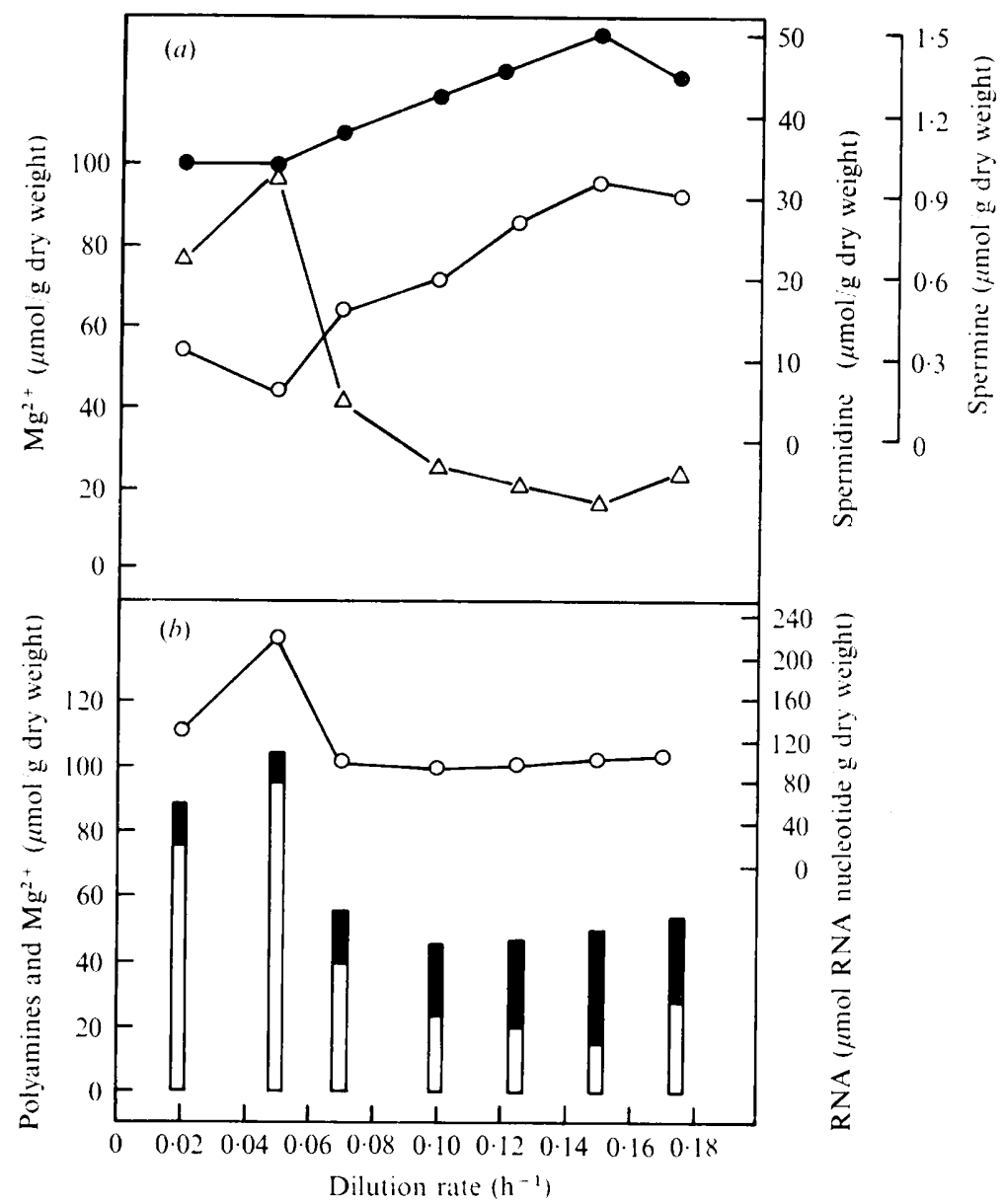

Fig. I. The influence of dilution rate on hyphal contents of spermidine, spermine, $\mathrm{Mg}^{2+}$ ions and total ribonucleic acid. (a) Spermidine $(O)$, spermine $(\bullet), \mathbf{M g}^{2+}(\triangle)$. (b) Total polyamines (solid histograms), $\mathbf{M g}^{2+}$ (open histograms), total RNA (O). All values are of steady-state concentrations.

\section{RESULTS AND DISCUSSION}

Mycelial concentrations of magnesium, spermidine and spermine as a function of growth rate are shown in Fig. I (a). Magnesium concentrations varied nearly sixfold ( 8 to $97.5 \mu \mathrm{mol} /$ $\mathrm{g}$ dry weight) and fell dramatically with increasing dilution rate. An average value of 97.5 $\mu \mathrm{mol} / \mathrm{g}$ dry weight for the $\mathrm{Mg}^{2+}$ concentration of vegetative bacteria is evident from Tempest's (1969) data and this is equivalent to an approximate molar concentration of I $50 \mathrm{~mm}$. We have not estimated the internal water of Aspergillus nidulans mycelia, but using the value obtained by Viotti, Bagni, Sturani \& Alberghina (1971) for young mycelia of Neurospora crassa, the magnesium concentration of $A$. nidulans varied over the approximate range 6 to $37 \mathrm{~mm}$. The $\mathrm{Mg}^{2+}$ concentration of exponentially growing $N$. crassa was $16 \mathrm{~mm}$ (Viotti et al. I97I). In contrast to $\mathrm{Mg}^{2+-}$, spermidine and spermine concentrations of $A$. nidulans increased as the dilution rate was raised; spermidine increased from $6 \mu \mathrm{mol} / \mathrm{g}$ dry weight ( $2.9 \mathrm{mM}$ ) to $32 \mu \mathrm{mol} / \mathrm{g}$ dry weight (I $5.4 \mathrm{~mm}$ ) and spermine from $\mathrm{I} \cdot 0 \mu \mathrm{mol} / \mathrm{g}$ dry weight $(0.40 \mathrm{~mm})$ to $\mathrm{I} .5 \mu \mathrm{mol} / \mathrm{g}$ dry weight $(0.59 \mathrm{~mm})$. Comparable values for exponentially 
growing $N$. crassa were $16 \mathrm{~mm}$ and $0.22 \mathrm{~mm}$, respectively (Viotti et al. 197I). These data take on a special significance when they are related to the steady-state RNA concentrations in the mycelia. The molar ratio of $\mathrm{Mg}^{2+}$ to RNA does not vary with dilution rate in carbonlimited cultures of bacteria (see Tempest, 1969) but our data from Aspergillus nidulans show marked variations (Fig. I b). However, when the polyamines are considered, the molar ratio of polyamines plus $\mathrm{Mg}^{2+}$ to RNA remained constant at approx. 2: $\mathrm{I}$. It seems therefore that the synthesis of the polyamines, and spermidine in particular, changes in response to growth-rate dependent fluctuations in $\mathrm{Mg}^{2+}$ in such a way that the cation to RNA ratio is maintained. Whether this ratio is critical for the stability of ribosome complexes or for RNA synthesis, and to what extent polyamines are functionally interchangeable with $\mathrm{Mg}^{2+}$ ions, are as yet unanswered questions. The ratio of total cation (polyamine plus $\mathrm{Mg}^{2+}$ ) to RNA remained constant only under conditions of vegetative growth and changed significantly in the heterogeneous culture of spores and mycelium (dilution rate $=0.02 \mathrm{~h}^{-1}$ ). This effect would seem predictable when one considers the large turnover of RNA during conidiation (Righelato, Trinci, Pirt \& Peat, I968) and the change in ribosome efficiency which occured when the dilution rate was decreased to $0.02 \mathrm{~h}^{-1}$ (Bushell, McGetrick \& Bull, 1973).

Why the internal $\mathrm{Mg}^{2+}$ concentration falls with increasing dilution rate also requires investigation. Perhaps this reflects a progressively impaired magnesium-assimilation mechanism, as preliminary chemical analyses of the hyphal wall (A. M. T. McGetrick \& A. T. Bull, unpublished data) have revealed that its net negative charge and uronic acid content also decreased as the dilution rate was raised. How much, if any, of the total mycelial $\mathrm{Mg}^{2+}$ and polyamines are bound to the wall polyuronates has not been determined but further analyses of this type are to be made.

The chemostat provides an ideal system for investigating interrelated phenotypic changes in microbial chemistry and function. Magnesium-limited chemostats are currently being used for further resolving the changes reported in this paper.

We thank Dr R. B. Freedman for providing facilities for fluorescence spectrometry.

\section{REFERENCES}

Bull, A. T. \& Faulkner, B. M. (1965). Melanin synthesis in wild-type and mutant strains of Aspergillus nidulans. Journal of General Microbiology 4r, iv.

Bushell, M. E., McGetrick, A. M. T. \& Bull, A. T. (1973). Chemostat culture of Aspergillus nidulans. Further analyses of kinetic and physiological parameters. Proceedings of the Society for General Microbiology $\mathbf{1}, 23$.

Carter, B. L. A. \& Bull, A. T. (1969). Studies of fungal growth and intermediary carbon metabolism under steady and non-steady state conditions. Biotechnology and Bioengineering II, 785-804.

CoHEN, S. S. (197I). In Introduction to the Polyamines. Englewood Cliffs, N.J., U.S.A.: Prentice-Hall.

Dion, A. S. \& Herbst, E. J. (1970). Polyamine changes during development of Drosophila melanogaster. Annals of the New York Academy of Sciences 171, 723-734.

Herbert, D., Phipps, P. J. \& Strange, R. E. (1971). Chemical analysis of microbial cells. In Methods in Microbiology, vol. 5 B, pp. 209-344. Edited by J. R. Norris and D. W. Ribbons. London: Academic Press.

Righelato, R. C., Trinci, A. P. J., Pirt, S. J. \& Peat, A. (I968). The influence of maintenance energy and growth rate on the metabolic activity, morphology and conidiation of Penicillium chrysogenum. Journal of General Microbiology 5o, 399-412.

Rowley, B. I. \& Bull, A. T. (1973). A chemostat for filamentous moulds. Laboratory Practice 22, 286-289.

TEMPEST, D. W. (1969). Quantitative relationships between inorganic cations and anionic polymers in growing bacteria. In Microbial Growth. Symposium of the Society for General Microbiology 19, 87-1II.

Viotti, A., Bagni, N., Sturani, E. \& Alberghina, F. A. M. (I97I). Magnesium and polyamine levels in Neurospora crassa mycelia. Biochimica et biophysica acta 244, 329-337. 